\title{
A preliminary seismic interpretation of an area with extensive Tertiary basalts offshore central West Greenland
}

\author{
Richard C. Whittaker
}

A seismic and geological interpretation of the area between latitudes $67^{\circ} 30^{\prime} \mathrm{N}$ and $73^{\circ} \mathrm{N}$ offshore West Greenland, was completed in 1995 and has been published as an Open File Series report (Whittaker, 1995). The area is characterised by extensive Early Tertiary basalts which are the seaward extension of the plateau basalts exposed in the Disko - Nuussuaq - Svartenhuk Halv $\varnothing$ area onshore (Clarke \& Pedersen, 1976). These basalts present special problems in the processing and interpretation of seismic data. The interpretation incorporates all the seismic data acquired prior to the 1995 field season, including those lines acquired during the first phase of exploration in the $1970 \mathrm{~s}$. Ties to two of the exploration wells drilled offshore southern West Greenland have led to a greater understanding of the timing and kinematics of tectonic events during the Tertiary period; such events are not recorded in the onshore area. The area is considered to have significant exploration potential and warrants additional studies to determine the thickness of the basalt formation in the area.

\section{Background}

This interpretation completes the final stage of a major seismic project involving the interpretation of all the newer seismic data in West Greenland from the Melville Bay area in the north (Whittaker \& Hamann, 1995) to the entire continental shelf of southern West Greenland in the south (Chalmers et al., 1995).

The area covered in this study extends approximately $600 \mathrm{~km}$ from latitudes $67^{\circ} 30^{\prime} \mathrm{N}$ to $73^{\circ} \mathrm{N}$ and $200 \mathrm{~km}$ from east to west (Fig. 1). This large underexplored region is important to regional geological understanding and to petroleum exploration in West Greenland as a whole. Seismic data in the area provide a means of correlating geological data from the five offshore oil exploration wells in southern West Greenland with the Melville Bay area which is believed to have outstanding exploration potential. Information gained from this study will also be useful in the assessment of the adjacent Disko - Nuussuaq - Svartenhuk Halv $\emptyset$ area where a commercial exploration programme has begun. The discovery onshore of oil shows in basalts on Nuussuaq (Christiansen et al., 1996) has also upgraded the potential for an offshore sub-basalt oil play.
Water depths over most of the continental shelf in the area described are between $100 \mathrm{~m}$ and $500 \mathrm{~m}$, with a significant proportion shallower than $200 \mathrm{~m}$. Physical conditions in the area are, however, harsh. The sea freezes over in November, and the sea-ice does not break up until June (Thomsen, 1993). Scattered large icebergs derived from glaciers draining the Greenland Inland Ice are present throughout the year. However, experience has shown that geophysical surveys can be carried out in the summer field season with very little down-time, and offshore oil exploration wells were drilled farther south as long ago as 1976.

\section{Seismic interpretation}

The seismic data interpreted during this study vary considerably in quality and resolution. Approximately $2500 \mathrm{~km}$ of modern multifold reflection seismic data were acquired in the area during surveys carried out in 1990 and 1992. In addition there are $4000 \mathrm{~km}$ of older seismic data, acquired by the oil industry during the first phase of oil exploration in the 1970s; these are generally of poor quality but are still useful in defining structural trends and in mapping horizons.

A total of eight horizons were picked on the seismic lines and depth converted using the ECHO mapping system. These horizons were then contoured to produce a series of structural maps and the probable geological age of these horizons has been assessed. The structure contour map of the top of the Tertiary volcanics horizon is shown in Fig. 1. In general, age determination becomes less reliable farther north in the area, away from the well control, and horizons beneath the top of the Tertiary volcanics are of a more speculative nature.

Before the start of the study it was assumed that it was not possible to see reflectors beneath the thick Tertiary volcanic section. Closer inspection of the data, however, has shown that it is possible to interpret horizons deeper than the top of the volcanics, and a thick Cretaceous sedimentary section is inferred to be present.

Cretaceous sediments encountered in the Ikermiut- 1 well can be tied directly into the south-east corner of the area where the Tertiary basalts are absent. The eastern end of seismic line GGU/90-4 (Figs 1,2) has a section about 


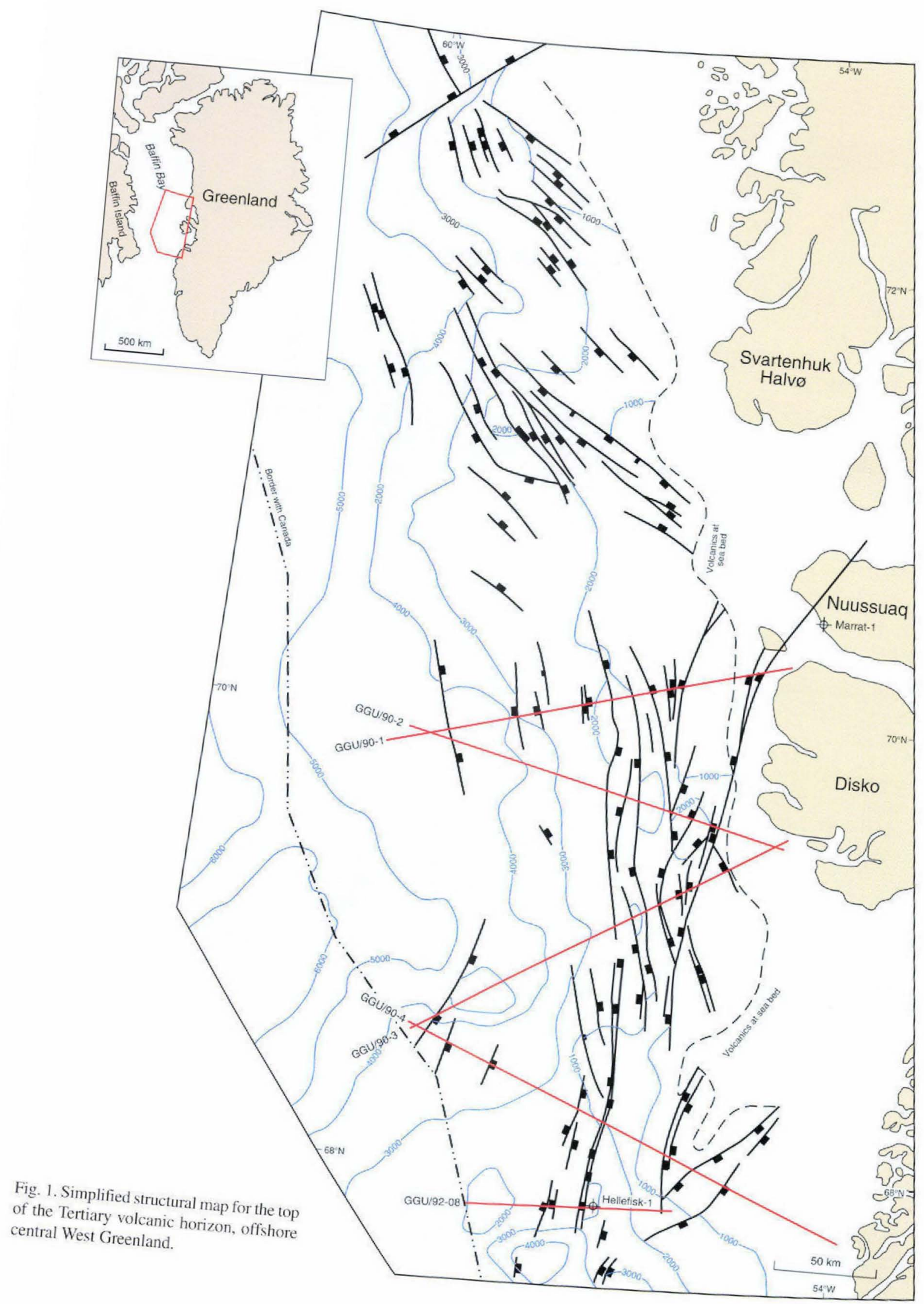



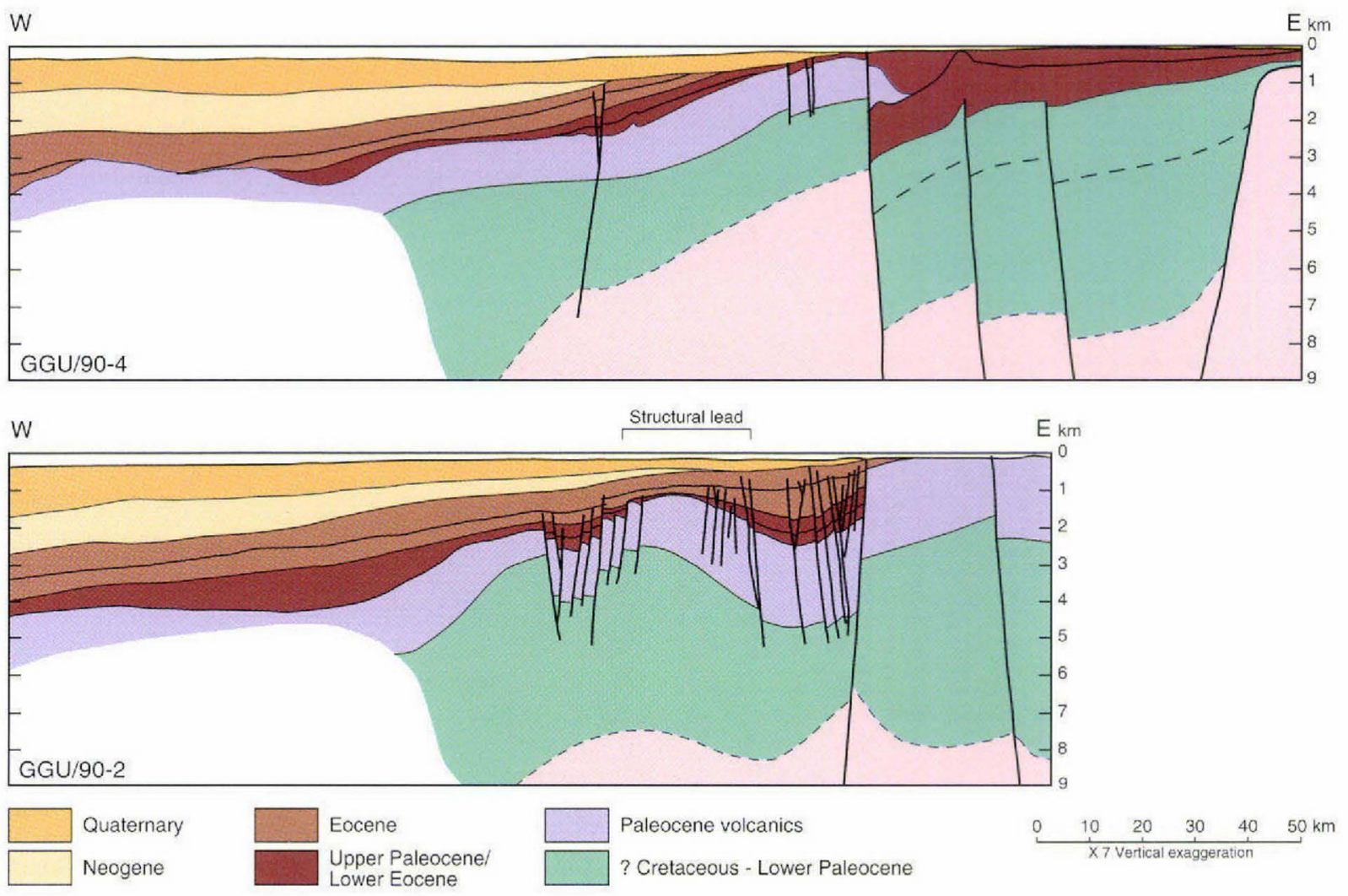

Fig. 2. Cross-sections drawn from depth-converted seismic lines GGU/90-2 and GGU/90-4, central West Greenland. Location of crosssections shown on Fig. 1.

$6000 \mathrm{~m}$ thick below the base of the Tertiary. Seismic lines to the west of Disko (line GGU/90-2, Figs 1,2) also show the presence of deep reflectors which are interpreted as Cretaceous sediments up to $5000 \mathrm{~m}$ thick. Internal reflectors can clearly be seen within the volcanic interval and in several places dipping reflectors can be seen to subcrop at the top of the Tertiary volcanics horizon. This truncation of the top of the basalts indicates that substantial erosion of the volcanic interval took place during the Early Tertiary.

Upper Paleocene and younger sediments can be tied to the Hellefisk-1 well, drilled in the southern part of the area. Post-volcanic sediments occur throughout the area, except where basalts outcrop at the sea bed (Fig. 1). The basal part of the Eocene section onlaps topographic highs, and thickness changes within this interval indicate that sedimentation at this time was controlled by structure and the southern limit of the basalts.

A second major regional unconformity can be seen at the base of the Neogene section. The overlying sediments onlap towards the east, and gradually thicken towards Baffin Bay, reaching a maximum thickness of $2000 \mathrm{~m}$ in the west. The overlying Pliocene - Quaternary interval is a prograding sedimentary wedge which, in the south- eastern part of the area, was deposited in deep channels or canyons.

\section{Tectonic implications}

Thick Cretaceous rift deposits are interpreted to be present in the area but poor seismic resolution in this interval, caused by the overlying thick Tertiary volcanic section, results in a lack of detailed information about this phase in the development of the basin. An early extensional period is known to have affected other nearby areas (Chalmers et al., 1995). The Tertiary tectonic development can, however, be resolved with more clarity.

The northern and southern margins of the offshore basalts are controlled by NE-SW trending faults; this is also the direction of opening of the Labrador Sea during the extrusion of the basalts. Shale diapirs and shale-cored folds trending NW-SE are seen immediately north and south of the basalts.

Compressional structures, also seen in the Melville Bay area (Whittaker et al., submitted), are confirmed to have developed towards the end of a period of extension in the Paleocene (Fig. 2). These structures are believed to have 
resulted from transpression in a major transform zone, the Ungava Fracture Zone, which links the Baffin Bay oceanic basin to the Labrador Sea in the south. The structures formed in the Late Paleocene - Early Eocene, at about the end of the first phase of sea floor spreading in the Labrador Sea, and continued to develop after the extrusion of the Early Tertiary plateau basalts. Sea floor spreading in Baffin Bay does not appear to have begun until after the period of basalt extrusion (Whittaker et al., submitted).

The onset of sea floor spreading was followed by a relatively quiet period of thermal subsidence, with less active extensional faulting gradually dying out towards the end of the drift phase. The crests of anticlines formed during the phase of inversion were eroded in a period of Eocene syn-drift deposition, when transgressive marine sediments filled restricted basins in the irregular topography.

Steep faults penetrating the drift phase sediments are probably strike-slip faults related to the oblique spreading of Baffin Bay. The direction of sea floor spreading in Baffin Bay was roughly north-south, as was the second phase of spreading in the Labrador Sea. Strike-slip faulting continued to affect the region throughout the Eocene, with the formation of north-south transtensional grabens and NW-SE extensional faults.

Sea floor spreading is generally assumed to have continued until about the Oligocene-Eocene boundary (Srivastava, 1978); subsequently sedimentation took place by simple progradation into the Baffin Bay Basin. Seismic data from the study area indicate that there was a later period of subsidence, uplift and erosion. There is also evidence from the Labrador Sea and south-east Baffin Island that a high relief was established in the onshore areas during the Late Oligocene, and that uplift was renewed in the Late Miocene (Trettin, 1991). An indication of the minimum postPaleocene uplift onshore West Greenland is provided by the occurrence of Early Paleocene marine mudstones at about $1000 \mathrm{~m}$ above sea level. The western part of the offshore area, however, does not appear to have been affected by this uplift and is now at the maximum depth of burial.

\section{Petroleum potential}

Several promising structural leads have been mapped at top volcanics level (Fig. 1), and cross-sections drawn from depth-converted seismic sections also illustrate the presence of large structural leads (Fig. 2). The most promising potential plays in the area are sub-basalt Cretaceous and Lower Paleocene plays which are also the primary objective outside the offshore basalt area. A possible secondary Tertiary objective identified above the basalts may also have a significant potential and could be present in other areas offshore West Greenland. The shallower potential reservoirs are anticipated to be Upper Paleocene - Lower Eocene shallow marine and delta-front sandstones similar to those encountered in wells in the Labrador Sea. A source for hydrocarbons could occur in the restricted basins which are interpreted to be present in the Paleocene.

The thick basalt section may yet prove an insurmountable obstacle to the prospectivity of the area, but this study is sufficiently encouraging to warrant continued exploration. Partly as a result of this study, additional seismic data were acquired in the area during the summer of 1995 (Christiansen et al., this report).

\section{References}

Chalmers, J. A., Dahl-Jensen, T., Bate, K. J. \& Whittaker, R. C. 1995: Geology and petroleum prospectivity of the region offshore southern West Greenland - a summary. Rapp. Grønlands geol. Unders. 165, 13-21.

Christiansen, F. G., Bojesen-Koefoed, J., Dam, G., Nytoft, H.-P., Larsen, L. M., Pedersen, A. K. \& Pulvertaft, T. C. R. 1996: The Marraat oil discovery on Nuussuaq, West Greenland: evidence for a latest Cretaceous-earliest Tertiary oil-prone source rock in the Labrador Sea-Melville Bay area. Bull. Can. Petrol. Geol. 44, 39-54.

Clarke, D. B. \& Pedersen, A. K. 1976: Tertiary volcanic province of West Greenland. In Escher, A. \& Watt, W. S. (ed.) Geology of Greenland, 364-385. Copenhagen: Geological Survey of Greenland.

Srivastava, S. P. 1978: Evolution of the Labrador Sea and its bearing on the early evolution of the North Atlantic. Geophys. J. R. Astron. Soc. 52, 313-357.

Thomsen, H. H. 1993: Ice conditions offshore West Greenland. Rapp. Grønlands geol. Unders. 159, 43-47.

Trettin, H. P. 1991: Middle and Late Tertiary tectonic and physiographic developments. In Trettin, H. P. (ed.) Geology of the Innuitian orogen and Arctic Platform of Canada and Greenland. Geology of North America E, 493-496 (also Geology of Canada 3, 493-496. Geological Survey of Canada). Boulder, Colorado: Geological Society of America.

Whittaker, R. C. 1995: A preliminary assessment of the structure, basin development and petroleum potential offshore central West Greenland. Open File Ser. Grønlands geol. Unders. 95/9, $33 \mathrm{pp}$.

Whittaker, R. C. \& Hamann, N. E. 1995: The Melville Bay area, North-West Greenland - the first phase of petroleum exploration. Rapp. Grønlands geol. Unders. 165, 28-31.

Whittaker, R. C., Hamann, N. E. \& Pulvertaft, T. C. R. submitted MS: A new frontier province offshore northern West Greenland: basin development and petroleum potential of the Melville Bay area. Bull. Am. Ass. Petrol. Geol.

R. C. W., Geological Survey of Denmark and Greenland, Copenhagen 